\title{
En busca de un nuevo rostro: fotografías de un discurso dictatorial. Chile, 1973-1976
}

\author{
In search of a new identity: photographies about a \\ dictatorial ideology. Chile, 1973-1976
}

\author{
Lorena Berríos Muñoz \\ Universidad de Chile \\ lorenaberriosm@gmail.com
}

\begin{abstract}
Resumen
Si señalamos que la fotografía, como objeto cultural, no puede existir al margen de los discursos o funciones de algún tipo; como práctica depende de las instituciones y agentes que la definen. Desde esta perspectiva, la función que cumplió la fotografía en un régimen dictatorial -como el del caso chileno- estuvo estrechamente ligada a la inculcación e imposición de una sociedad disciplinada. A partir de ello, es que a través de la circulación de las fotografías en los aparatos comunicaciones y especialmente en la obra fotográfica Chile: Ayer y Hoy de la Editorial Nacional Gabriela Mistral, nos interesa revelar los anhelos, comportamientos y discursos que la Junta Militar pretendió infundir dentro de la sociedad.
\end{abstract}

Palabras clave: Chile, fotografía, dictadura, políticas comunicacionales, medios de comunicación, discursos visuales.

\begin{abstract}
If we indicate that the photography, as cultural object, cannot exist to the margin some ideologies or some types of functions. Its practical essence depends on the institutions and the agents that, eventually, define it. From this point of view, the role photography played during the Chilean dictatorial government was strictly related to the social discipline imposed. From these facts, through the spread of the photos, of the means of communication and, especially, through the photographic work Chile: Ayer y Hoy (Gabriela Mistral Publishing House), we are highly interested in revealing the wishes, behaviors and speeches the Military Junta expected to instill in the population.
\end{abstract}

Keywords: Chile, photography, dictatorship, communicational policies, means of communication, visual discourses. 


\begin{abstract}
Ver y representar son actos 'materiales' en la medida en que se constituyen medios de intervenir el mundo. No 'vemos' simplemente lo que esta allí, ante nosotros, más bien, las formas específicas como vemos -y representamosel mundo determinan cómo es que actuamos frente a éste y, al hacerlo, creamos lo que ese mundo es.

Deborah Poole.
\end{abstract}

El ambiente de la mañana del 11 de septiembre de 1973 es denso y silencioso. Sin embargo, aquel silencio termina cuando un gran estruendo se siente en el centro de Santiago. Una junta militar toma el poder y Salvador Allende muere en La Moneda. Después de ocho días de aquel acontecimiento, las imágenes de La Moneda en llamas y de los soldados registrando y golpeando a los civiles en las calles céntricas de la ciudad, comenzaron a recorrer el mundo entero.

Durante el transcurso de las primeras semanas el país organizó sus actividades cotidianas según los diferentes bandos militares que se difundían en los medios de comunicación. Debemos recordar que hubo un estado de sitio permanente, restringiendo toda manifestación individual y colectiva.

Hacia finales del mes de septiembre, los reportajes concernientes a Chile por parte de las agencias extranjeras se concentraron especialmente en las acciones de la Junta Militar. Los primeros bandos y decretos presentan la primera vía de su legitimación, basada en un nuevo discurso autodenominado 'restauración democrática'; en ellos se invoca una serie de argumentos justificatorios de la toma del poder (bando No 5 y el decreto de ley No 1 ). A la luz de lo ocurrido, algunos medios más osados y críticos de los hechos acaecidos publicaron los primeros movimientos de la Junta y las características de la represión que vivía el país. Newsweek sugirió -en la primera semana de octubre- que el golpe no era un pronunciamiento militar de rutina, si no, el inicio de una dictadura militar que buscaba perpetuarse en el poder. "Los militares chilenos tenían en mente más que un simple cambio de gobierno -señalo Newsweek la primera semana de octubre-, nada menos que una revolución cultural de derecha" (Vergara: 2003, p48).

De hecho, los primeros días del mes de octubre la Junta Militar reaccionó a las fuertes críticas que los reporteros enviaban a sus respectivos países. Un ejemplo de ello fue la expulsión de cuatro reporteros, El Mercurio nos cuenta: "cuatro periodistas extranjeros que ingresaron al país después del 11 de septiembre y cuyas residencias no han podido ser ubicadas por la policía, deberán abandonar Chile en las próximas 24 horas. La información fue entregada por la oficina de RR.PP. de la policía civil y afecta a los periodistas Grazie Mary Cervi, Philippe Labreveux, Leif Person y Peter Sumberd" (1973, 15 de Octubre). 
A partir de ese entonces y producto de las impactantes imágenes que comenzaron a circular en los medios de información internacional, la Junta Militar optó por enviar representantes al extranjero, quienes divulgaron la versión oficial -y limpia- del pronunciamiento ${ }^{1}$. El diario El Mercurio defendió a la Junta aclarando que:

Dicha incomprensión exterior es una ventaja porque permite mostrar al pueblo quienes son los que de veras resguardan la soberanía, la independencia y la dignidad de Chile, y quienes han actuado en el país como agentes de potencias extranjeras. Las voces chilenas que se oyen en Radio Moscú y los otros que mueven hilos en distintas capitales del mundo para lograr beneficios políticos partidistas u otras ventajas, sobre la base de desfigurar los propósitos y realidades del pronunciamiento militar chileno, son los que realmente conspiran contra la seguridad interior y exterior de la república y se hacen reos de traición a la patria (La incomprensión exterior, 1973, 7 de octubre).

Al mismo tiempo, comenzó una fuerte campaña en los medios nacionales desprestigiando al gobierno de la Unidad Popular para buscar el apoyo en la población:

Podemos asegurar que los efectos de la máquina publicitaria UP están latentes en los chilenos, y lo que es aún más negativo, es que si bien existe un grupo franco y claro hacia el nuevo gobierno, hay temor a comprometerse públicamente con él. Existe un actuar comprometido sólo a nivel individual y/o privado. Se le hace difícil a la población hacer trascender su apoyo (Sobre la necesidad de realizar una campaña Psicológica-masiva tendiente a destruir al marxismo como ideología, 1974, pp. 2-3).

Como vemos, la Junta debía arremeter fuertemente contra las críticas en el exterior, como también, aislar a la población de ideas revolucionarias que llevaran a provocar un derrocamiento del nuevo grupo dominante. La creación de un discurso hegemónico se hizo inminente (Ver lámina №1). La Junta Militar y sus adherentes se vieron en la encrucijada de legitimar sus actos por medio de la creación de un discurso unívoco, que se vio reflejado en los diferentes procedimientos llevados a cabo durante la dictadura. En ellos se expresa explícitamente la labor de forjar un nuevo rostro para Chile. Tomando las palabras de la Junta militar: "El rostro de Chile ha cambiado, y ha resurgido su espíritu y su alma” (A seis meses de la liberación nacional, 1974, 44). El Estado debía ser el único

\footnotetext{
${ }^{1}$ Los primeros meses del golpe de Estado se organizó una operación de imagen tanto en el interior como en el exterior. Concerniente a la imagen de chile en el exterior se decretó, el 19 de noviembre de 1973, el aumento de las plazas de "adictos culturales". Según Ascanio Cavallo éstas fueron aumentadas de diez a veinticinco. Los agentes culturales y de prensa tenían la misión de procurar que en los medios de comunicación no parecieran nada sobre Chile y si tuvieran lugar alguna noticia sobre el país debían resguardar que se hiciese en forma positiva (Cavallo, 1997).
} 
portavoz de ese ser nacional, rostro plausible que contuviera los valores esenciales de la patria que el marxismo ponía en peligro. Para la Junta Militar "el nacionalismo chileno, más que una ideología, es un estilo de conducta, la expresión genuina del ser de la Patria y del alma de su pueblo" (A seis meses de la liberación nacional, 1974, p38).

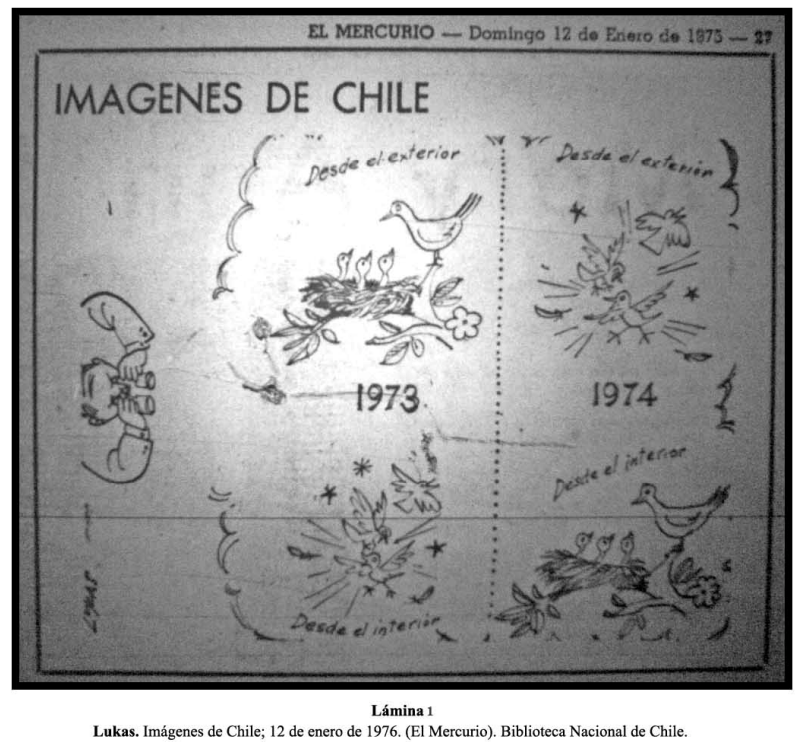

Es por ello que planteamos que las políticas comunicacionales, apuntaron a fortalecer una idea-imagen acorde con los principios legitimadores y restauradores fundados por la Junta. Las políticas comunicacionales delimitaron los parámetros discursivos que se debían utilizar en la implantación de un nuevo imaginario social, ya que estos eran una pieza efectiva del dispositivo de control de la vida colectiva, y en especial del ejercicio del poder.

A la luz de estos antecedentes es que nos interesó indagar en las ideas-fuerza que tuvo el Gobierno Militar y en lo que se comunicaba a través de la imagen fotográfica, sobre todo en aquellas que circulaban y eran conocidas, más que en aquellas que se internalizaban individualmente. A fin de cuentas, el único indicador posible de reconocimiento no es un estado mental, sino una nueva producción de significados.

En la actualidad resulta evidente que la fotografía no es una producción de imágenes inocentes como muchos pensaban antes, una simple reproducción de la naturaleza o una 
realidad objetiva del mundo que nos rodea, sino más bien un lenguaje relativamente estructurado tanto en sus formas como en sus significados. Si para la crítica postmoderna, la fotografía como tecnología varía según qué relaciones de poder la impregnan, no podemos dejar de sospechar de ella ${ }^{2}$. La fotografía, aunque estrictamente unida a la naturaleza, sólo tiene una objetividad ficticia; el carácter aparentemente no simbólico, de 'objeto' de las imágenes técnicas hace que el observador las mire y observe como si no fueran realmente imágenes, sino una especie de ventana al mundo. No obstante, el lente, ese ojo supuestamente imparcial, permite todas las deformaciones posibles de la realidad.

De esta manera, las fotografías que describe esta investigación se utilizaron como verdaderas herramientas que minaron el imaginario colectivo en la sociedad. Es por ello que proponemos que las imágenes fotográficas que circularon en los aparatos comunicacionales se constituyeron y circularon bajo determinadas estructuras, impuestas dentro de los parámetros establecidos por las políticas comunicacionales. Es así, que las imágenes fotográficas como tecnología de representación se convierten en un problema de actores sociales y de sociedades y no de discursos abstractos. Es incluso al contrario, pues el discurso que en ellas se impregna tiene una presencia material y real en la historia.

Ahora bien, si analizamos en profundidad las políticas comunicacionales, estas fueron concebidas desde una acuciosa y metódica planificación, pues la filiación de la población hacia la Junta Militar debía ser inmediata. A través de la dominación simbólica en una sola idea-fuerza pretendieron uniformar el imaginario social. Para ello, era fundamental controlar los medios de comunicación, pues "todo poder apunta a tener un papel privilegiado en la emisión de los discursos que conducen a los imaginarios sociales, del mismo modo que busca conservar cierto control sobre los circuitos de difusión"(Baczko, 1999, p. 31). De esta forma, la junta utilizó los distintos medios de comunicación que existían en aquel entonces, la radio, la televisión y la prensa escrita.

Precisamente, las políticas comunicacionales estuvieron estructuradas en una doble dimensión. La primera afectó directamente a los aparatos comunicaciones y la segunda, estaba relacionada con la estructura del sistema informativo (Munizaga, 1983). Por un lado, los aparatos comunicacionales sufrieron un fuerte estrechamiento en la diversidad de los sistemas de comunicación mediante un control permanente y legalizado por medio de normas de emergencia. Por el otro, las transformaciones sociales incidieron en un cambio en la estructura del sistema informativo, a través de la desarticulación de una vasta red de organizaciones políticas y de la reestructuración de nuevos contenidos del material

\footnotetext{
${ }^{2}$ Nos referimos a las posturas señaladas por el crítico inglés John Tagg -influenciado por el marxismo estructuralista del francés Louis Althusser-, Allan Sekula -influenciado por el marxismo de György Lukács- y A. Burgin.
} 
comunicativo en la publicidad, con ello se produjo un cambio en la estructura de recepción.

Desde un principio los aparatos comunicacionales estuvieron regulados mediante la conformación de diferentes bandos, puntualmente, los № 12, 14 y 15. En ellos se estipuló una sola mirada de los acontecimientos, es decir, universalizaron arbitrariamente su pensamiento al resto de la sociedad: "La junta de Gobierno desea mantener informada a la opinión pública sobre los acontecimientos nacionales. De acuerdo con lo dispuesto en los Bandos hasta ahora emitidos y por encontrarse el país en Estado de Sitio, se ha dispuesto ejercer sobre los medios de publicación una estricta Censura de Prensa"(El Mercurio, 1973, 13 de septiembre). De esta forma, la justificación del acto de censurar se realizó en función de salvaguardar la estabilidad política que propició la Junta, por medio de la prohibición de las posibilidades de expresión en los medios de comunicación. Es decir, por medio de la censura se pretendió extender una idea fija de lo que se pretendía que la sociedad fuese; de esta forma, la institución censora debía resguardar la estabilidad o la naturaleza propia de la sociedad, de acuerdo a los principios que emanaban de la Junta.

Para ello se censuraron los medios de comunicación, se clausuraron y expropiaron diarios como Clarín, Puro Chile, El siglo y La Nación; algunas revistas como Ramona, Punto Final y La Rueda ${ }^{3}$ dejaron de circular. Al mismo tiempo, desaparecieron editoriales como Quimantú y se clausuraron diversas radios como Balmaceda. Sólo se podía acceder a la coyuntura nacional a través del diario El Mercurio que pasó a ser el vocero oficial (legitimado por el poder político bajo el bando № 15 ), sustituyendo a las organizaciones intermedias -nos referimos a la multiplicidad de instancias que actúan bajo un gobierno democrático por medio de los partidos políticos, las agrupaciones gremiales, los sindicatos y las organizaciones estudiantiles- que cumplían una función de balance o contrapoder en los sistemas democráticos (Sunkel, 1983).

Con respecto a la segunda medida tomada por la junta, una de las formas de control de los sistemas informativos se dio mediante la introducción de nuevos contenidos. Se eliminaron vocablos como: clase, obrero, solidaridad, reivindicación, compañero o comuna; y fueron reemplazados por significantes de diferente carga sígnica como: patria, reconstrucción, limpieza, purificación, dignidad y progreso. Simultáneamente, el lenguaje de los dominadores (la Junta Militar y sus adeptos) se ve enfrentado a la necesidad permanente de recalificar, de cambiar el contenido histórico de las palabras. La democracia se transforma en nueva democracia, en democracia defendida, democracia autoritaria, como también, el sentido de patria, limpieza y dignidad.

\footnotetext{
${ }^{3}$ Para ello se había designado una oficina de Censura de Prensa, que funcionaba en la Academia Politécnica Militar del Ejercito (San Ignacio No 242), y que tuvo bajo su control las publicaciones escritas autorizadas (Bando No 15).
} 
A partir de noviembre de 1974 se realizaron verdaderos impactos psicológicos por medio de una campaña denominada Guerra Psicológica de Penetración. De hecho, "la campaña tiene como objeto fundamental actualizar los factores neurotizantes que traumatizaron al ciudadano chileno durante el régimen de la UP, y que, en muchos casos, pese a la alta significación ansiosa de que fueron objeto, actualmente lo han olvidados" (Campaña de Penetración Psicológica Masiva, 1974, p. 2).

Los medios de comunicación debían transmitir mensajes conscientes que gatillaran en el inconciente de cada ciudadano una reacción específica, como lo demuestran los documentos emitidos por Hernán Tuane como asesor civil de la Junta ${ }^{4}$. Para realizar dicho plan, se estipulan ciertos vínculos entre la idea de marxismo y sus diferentes calificativos (marxismo igual violencia, marxismo igual angustia) y la Junta Militar como factor terapéutico (Junta Militar igual bienestar, progreso y Patria).

En efecto, se utilizaron para ello una serie de imágenes que sobre el plano imaginario y simbólico reproducían y completaban un sistema de representaciones cerrado. Según Tuane: "A través de consignas repetidas. Es necesario aclarar que lo repetitivo es la idea involucrada. Debiéndose cada cierto tiempo ser cambiada las imágenes o sus ejemplos que acompañen a la idea que se trata de depositar en la mente individual y colectiva" (Preparación Psicológica de la población para contrarrestar la acción marxista, 1973 p. 5).

Tomando en cuenta lo anterior y al revisar las imágenes que comenzaron a circular en el diario El Mercurio observamos que se utilizaron caricaturas, imágenes fotográficas y determinados dibujos (en afiches) acompañados por ideas específicas acorde a lo propuesto por Tuane. Además, se crearon dispositivos de difamación contra el expresidente y su gobierno, ya que el único modo de deslegitimar el régimen anterior fue a través de sistemáticas publicaciones - negativas- sobre la Unidad Popular, como es el caso del Libro Blanco. Del cambio de gobierno en Chile y La experiencia socialista chilena. Anatomía de un Fracaso, segunda edición con 50 mil ejemplares 5 , (Ver lámina 2). Para Tuane se hacía:

necesario preparar psicológicamente a la población, ANTES que estos hechos se presenten; a modo que estos elementos activistas no puedan contar con el apoyo

\footnotetext{
${ }^{4}$ El psicólogo Tuane fue un hombre fiel al régimen de Pinochet. Se puso a disposición del proceso militar para encabezar el equipo que se encargó de planear y poner en práctica esta campaña, como también, el primer "asesinato de imagen" de Salvador Allende después del derrocamiento.

${ }^{5}$ Según El Mercurio, El Libro Blanco fue elaborado por La Secretaría General de Gobierno y consta de 264 páginas. Por otro lado, la divulgación en la época fue la siguiente: "Está siendo distribuido desde ayer en el país y será también especialmente divulgado en el extranjero. Además, en un pequeño prólogo la Secretaría General de Gobierno dice: 'El pueblo y el gobierno de Chile no tiene miedo alguno a la verdad, y con este Libro Blanco, la presenta con todos los antecedentes y pruebas a la opinión universal”' (El Mercurio: 1973, 27 de octubre).
} 
ciudadano. Para lograr estos objetivos se sugieren dos líneas de trabajo [donde la primera apunta a]:

1.- Lucha contra el movimiento UP en general. Esta campaña tendrá como finalidad la obtención de dos vínculos:

a) Marxismo (UP) equivalente a Mentira.

b) Marxismo (UP) equivalente a Traición.

c) Marxismo (UP) equivalente a Corrupción" (Preparación Psicológica de la población para contrarrestar la acción marxista, 1973, p3).

Se hicieron comunes noticias como: "Traficantes de drogas financiaban el MIR", "Descubrieron dinamita para hacer volar a toda Lota", "La UP protegía el tráfico de drogas", "Joan Garcés pretendía destruir Chuquicamata" o "Marxistas iban a reemplazar actual bandera”, con sus respectivas imágenes.

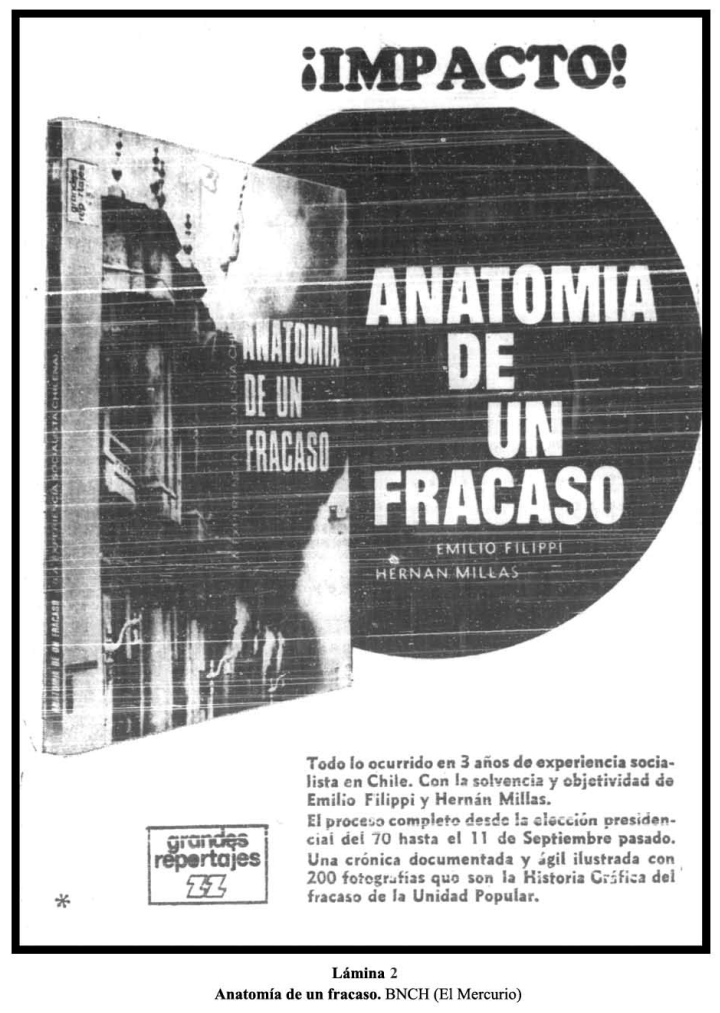


Como vemos en la lámina 3, texto e imagen juegan un rol fundamental al momento de reproducir una idea o concepto; ambos se necesitan para ser un todo. El pie de foto precisa de manera explícita el sentido de la imagen. El texto unido a la imagen produce efectos que son a la vez lingüísticos y narrativos, que se asocian entre sí. De esta forma, la imagen de un hombre que muestra una bolsa, posiblemente de cocaína no nos dice nada, es muda, sin embargo, el texto lo dice todo: "Por 30 mil dólares al mes. La UP protegía el tráfico de Drogas”. Según Félix del Valle Gastaminza:

La palabra aporta cierto número de informaciones que la imagen es incapaz de vehicular. Por un lado, sirve de guía al lector para optar entre los significados posibles de una acción representada visualmente. Además, da un sentido ideológico, de tal manera que ofrece un juicio sobre lo que la imagen no puede representar de un modo asertivo; así pues, da consignas al lector para que éste interprete lo que está viendo de una manera o de otra (2005, p. 223).

Es por ello que se hace coherente la imagen y pie de página, como también imagentexto con el tipo de contenido que se pretendía vincular. Recogiendo las palabras de Barthes "toda fotografía es contingente (por ello fuera de sentido), la fotografía sólo pude significar (tender a una generalidad) adoptando una máscara” (Barthes, 1992, p. 76). Careta que la misma dictadura le da a la imagen muda, donde el código de connotación no es natural ni artificial, sino histórico, y en este caso discursivo.

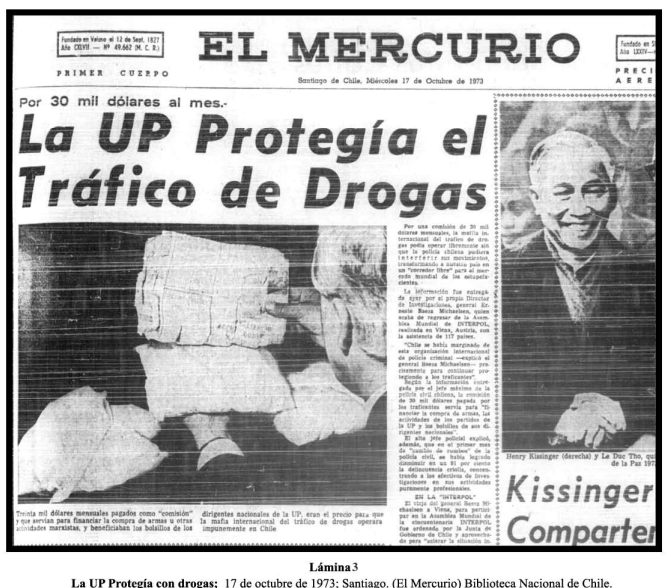

La UP Protegéa con drogas; 17 de octubre de 1973: Santiago. (El Mercurio) Biblioteca Nacional de Chile 
Conjuntamente, en las noticias publicadas se destacaba también la concientización de la población en un sentido positivo, de acuerdo a los postulados de la Junta Militar. Por consiguiente, columnas editoriales referentes a temas como la limpieza de la ciudad, especialmente de muros y calles-, fotografías y pies de página que apelan a la espontánea colaboración de la ciudadanía -sobre todo jóvenes universitarios, niños borrando las consignas políticas de los muros-, eran una forma de estimular la adhesión al nuevo orden establecido (Ver lámina 4, 5 y 6). No obstante, no debemos olvidar que existían expresas órdenes de limpiar aquellos murales "de modo que la población adquiera un aspecto de orden y aseo" (El Mercurio, 1973, 28 de septiembre). La "limpieza" de calles y muros con consignas políticas se referían específicamente a los murales realizados por los muralistas de la brigada Ramona Parra (juventudes comunistas), como también Inti Peredo (PS) y Elmo Catalán 6 . De hecho, uno de los titulares que dice "Aceleran al máximo la extracción de basura” (El Mercurio, 1973, sábado 22 de septiembre) se refiere, fundamentalmente, a las consignas en los muros de las calles en ciudades regionales y en la capital. Los murales realizados por las brigadas son valorados como basura, a diferencia de años anteriores donde se presentaban como muestras plásticas en el Museo de Bellas Artes (Cleary, 1988; León, 1983).

Si tomamos otro ejemplo y si observamos el cartel que nos muestra una mano con un anillo y debajo de ella una bandera acompañada de textos como "esta es mi Bandera", quiere manifestar a la población una identificación con el discurso a partir del referente patriótico de la imagen de la bandera (Ver lámina 7). La mano femenina representaba, a nuestro modo de ver, a la sociedad chilena que se desposaba con aquella mano masculina que protege manteniendo el ritual tradicional del matrimonio. Pero za quién le pedirá la mano si el gobierno ha sido derrocado? A la bandera, a la madre patria que son ellos mismos (la Junta), pues su función específica es defender los territorios y la patria, simbolizada en la bandera. La junta militar mantuvo su apoyo mediante pequeñas campañas inspiradas en ayudar a una gran meta denominada Reconstrucción Nacional. Este acto solidario como lo denomina Tuane "es un acto simbólico, una idea, la que se gratifica sólo frente al acto de dar" circunscrita a un hecho o acontecimiento específico (Sobre la necesidad de realizar una campaña Psicológica-masiva tendiente a destruir al marxismo como ideología, 1974, pp. 6-7).

\footnotetext{
${ }^{6}$ Estas brigadas fueron herramientas de propaganda entrecruzadas con la práctica artística, partir del aprendizaje y el quehacer de las organizaciones políticas con el lenguaje plástico realizado en los muros de las ciudades. El mural callejero habita el entorno social abierto y está en contacto con su arquitectura y la multitud, dialoga con él. El muralismo callejero concientizaba visualmente al espectador, educaba a través de la denuncia social, informaba a través de la consigna diaria de los acontecimientos. No obstante, la dictadura cambió los muros de colores de las ciudades por muros blancos, fríos y pulcros, sin ningún acontecimiento para informar.
} 


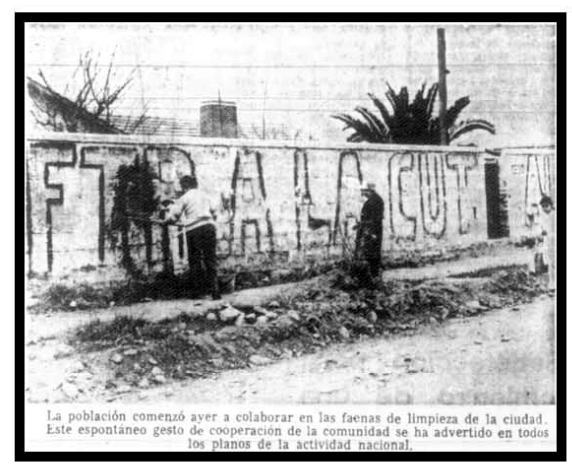

Lámina 4

Anónimo. La población comenzó ayer a colaborar en las faenas de limpieza en la ciudad. Este espontáneo gesto de cooperación de la comunidad se ha advertido en todos los planos de la actividad nacional; 17 de septiembre de 1973. (El Mercurio) Biblioteca Nacional de Chile.
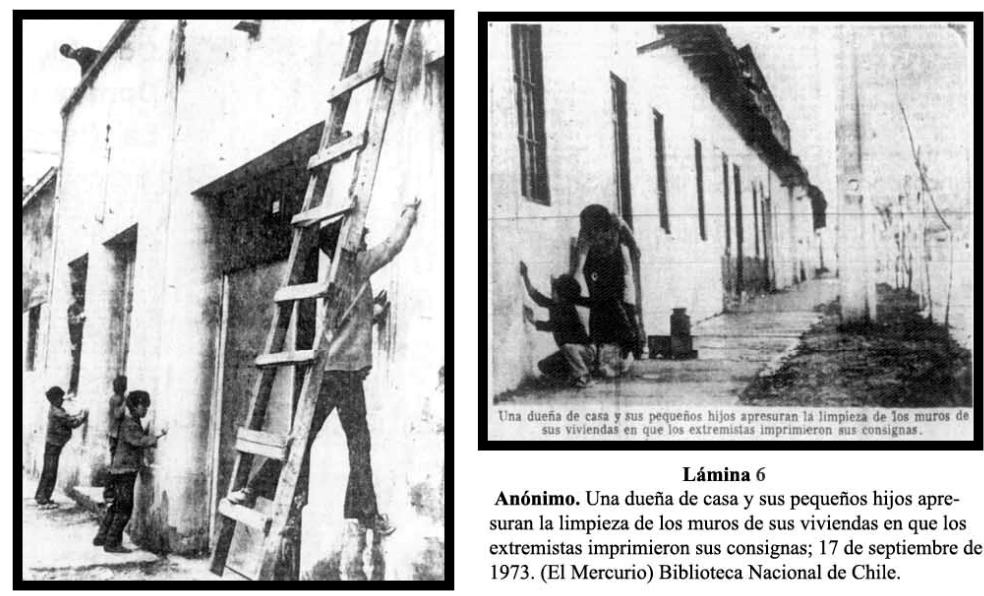

Lámina 6

Anónimo. Una dueña de casa y sus pequeños hijos apreAnónimo. Una dueña de casa y sus pequeños hijos apre-
suran la limpieza de los muros de sus viviendas en que los extremistas imprimieron sus consignas; 17 de septiembre de Lámina5

1973. (El Mercurio) Biblioteca Nacional de Chile.

Anónimo. Con gran actividad ha continuado en la capital y en ciudades de provincias la limpieza de murallas y frontis de edificios y residencias. En la Foto varios muchachos de corta edad realizan su labor con todo entusiasmo en los viejos murallones de Avenida Independencia; 28 de septiembre de 1973.(El Mercurio) Biblioteca Nacional de Chile.

Durante los meses de campaña se recibieron novedosas iniciativas como un film de carácter documental que realizaría la empresa Emelco, relatando los episodios posteriores 
al golpe, como vemos se repete la noción documento en una imagen en movimiento ${ }^{7}$. Otro ejemplo a destacar son las tarjetas postales que propone Teodoro Vache García, ex oficial de la Marina y actualmente jubilado de la Compañía Manufacturera de Papeles y Cartones. Dichas postales llevarían el slogan "Yo también coopero a la liberación de Chile" y su estructura formal sería similar a la que expendía la UNICEF para la Navidad (El Mercurio, 1973, viernes 12 de Octubre).

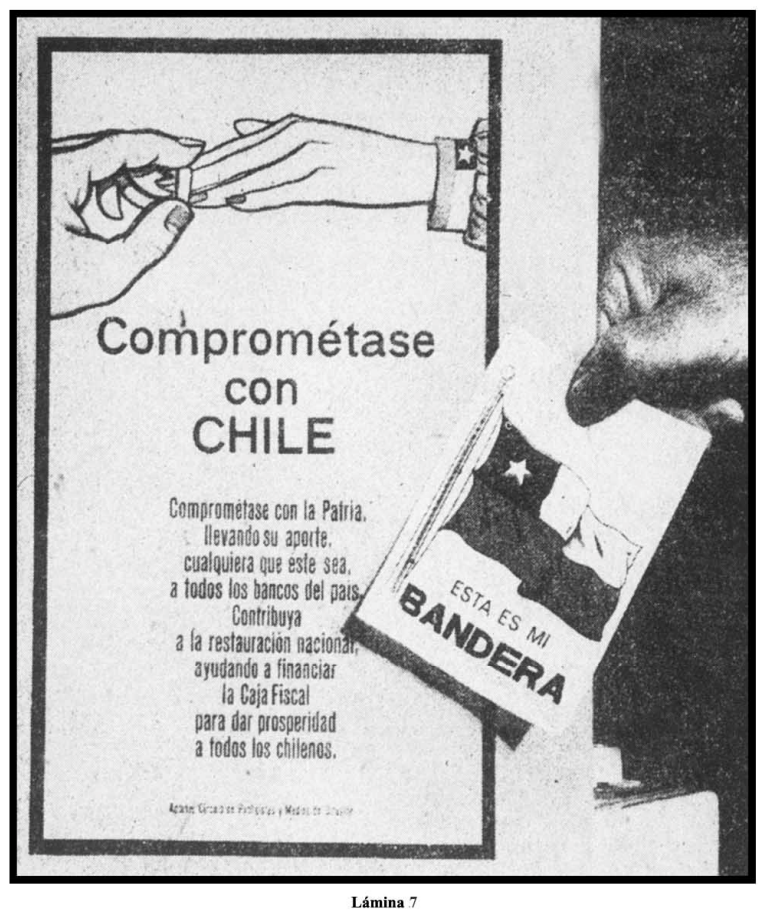

Comprométase con Chile; 2 de octubre de 1973.(El Mercurio) Biblioteca Nacional de Chile.

\footnotetext{
${ }^{7}$ Dicho film se tituló la Verdad sobre Chile y sólo se dio a conocer en 1977 por televisión abierta como lo registra El Mercurio. (Del Cine nacional. 'La verdad sobre Chile':1973, viernes 10 octubre); (Valioso Documental, 1977, 15 de septiembre).
} 
Con el mismo propósito, la Asociación de Impresores Gráficos (ASIMPRES) atendiendo al llamado de la Junta y "ante la distorsionada imagen, que interesadamente, se ha difundido en la prensa mundial sobre nuestro país, ha querido con el presente folleto ilustrar en forma gráfica la realidad que vivió Chile durante los tres años de Gobierno Marxista de Allende" (ASIMPRES, 1973). El documento Tres años de destrucción reproduce en forma gráfica y escrita los elementos esenciales de la ideología dictatorial. En el folleto se potencia la negación absoluta de las acciones de la Unidad Popular, la deslegitimación del gobierno y la difamación de la imagen de Salvador Allende. La marcada insidia a la ideología marxista subraya una territorialidad con respecto a otro utilizando la dinámica de oposiciones, ya que el marxismo representaba la muerte de la "esencia nacional", donde el portavoz oficial era la Junta.

Para el nuevo grupo dominante, la extirpación de los focos de infección debía ser de raíz, con el fin de purificar el cuerpo moral de la Patria. Las imágenes de una población y las casas del ex-gobernante reproducen las analogías metodológicas de oposiciones planteadas por Tuane: "a través de imágenes simples, que por sí solas den cuenta de la idea que se expresa. Ejemplo: Perrera de Tomás Moro comparada a viviendas callampas” (Preparación Psicológica de la población para contrarrestar la acción marxista, 1973, p. 4). La precariedad de un niño con pies desnudos connota la escasez versus la suntuosidad de la casa de Tomás Moro, intensificada con un imponente cocodrilo en la orilla de una gran piscina (Ver lámina No 8, 9, 10 y 11 ).
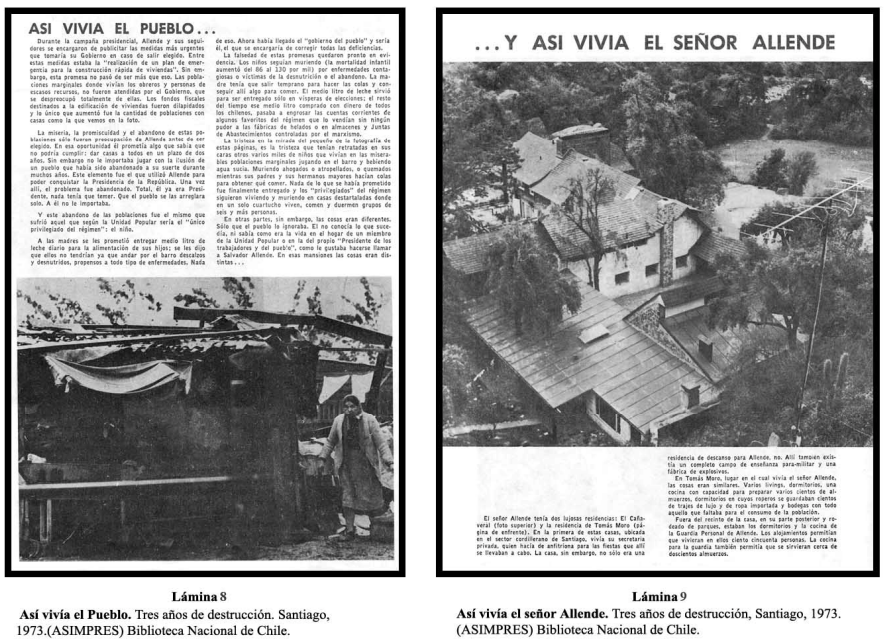


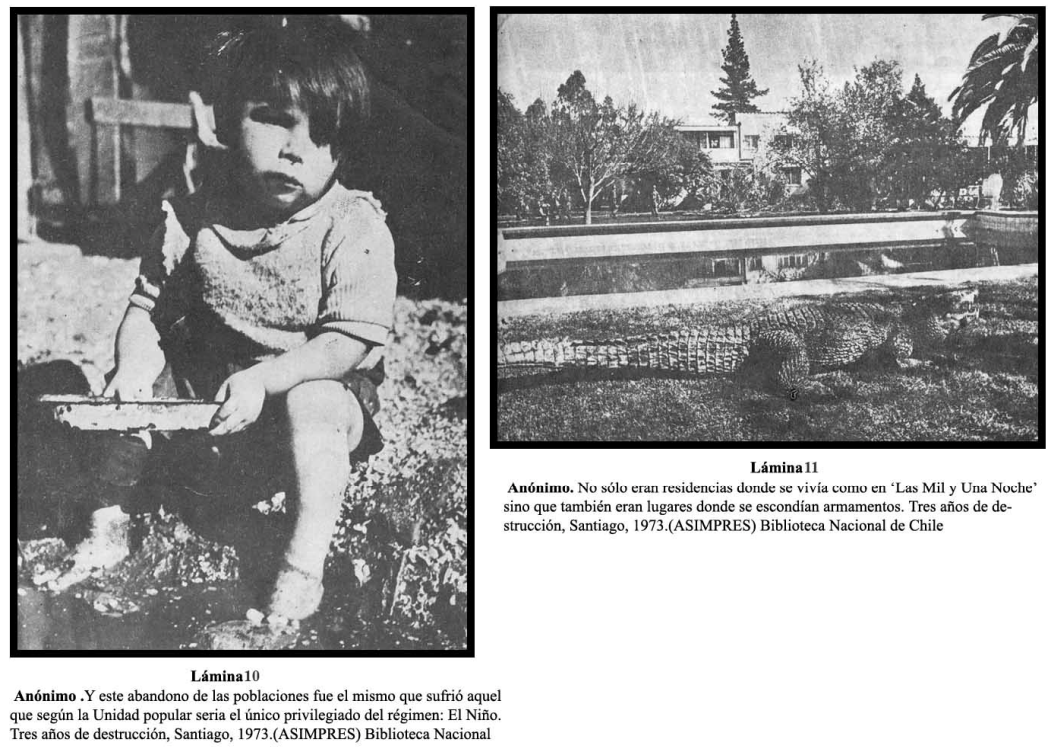

Ahora, bien, si revisamos un caso en el diario El Mercurio encontramos un afiche bajo la estructura de collage (Lámina №12). La imagen se presenta con un fondo negro y las fotografías sobrepuestas una sobre la otra, junto con el texto, armando un solo sentido. La disposición de las fotografías no es fortuita aunque el collage se caracteriza en su composición por una suma de elementos sin aparente relación; no obstante, el tipo de fotografías (de recortes) y el fondo utilizado en la parte superior y la parte inferior del afiche se vuelven unívocos. La composición es realizada por un ser ausente, no identificable, por lo tanto, el discurso es emitido por una fuerza superior institucionalizada.

Por otro lado, si analizamos estas fotografías podemos darnos cuenta de que fueron utilizadas en otras publicaciones. La fotografía superior, un hombre corriendo con un palo, la podemos encontrar en el diario El Mercurio el 5 de abril de 1973 y en Breve historia de la Unidad Popular, editado por el mismo medio de comunicación ${ }^{8}$ (Ver lámina No 13). Además, en el folleto entregado por Asimpres (Asociación de Impresores de Chile) a la Junta Militar la primera semana del mes de octubre, (como medio de apoyo y propaganda pro-golpe de Estado) utiliza las mismas imágenes. La fotografía del costado, dos hombres

\footnotetext{
${ }^{8}$ La autoría de la fotografía correspondería al fotógrafo Manuel Martínez, reportero gráfico de El Mercurio (Breve historia de la Unidad Popular, 1974).
} 
detrás de un mesón, es publicada en el mismo folleto mencionado con el titulo "el comienzo de una ruina" (Ver lámina № 14). Como vemos, las fotografías son recicladas y manipuladas con significados similares que proyectan, en su conjunto, una sola significación discursiva.

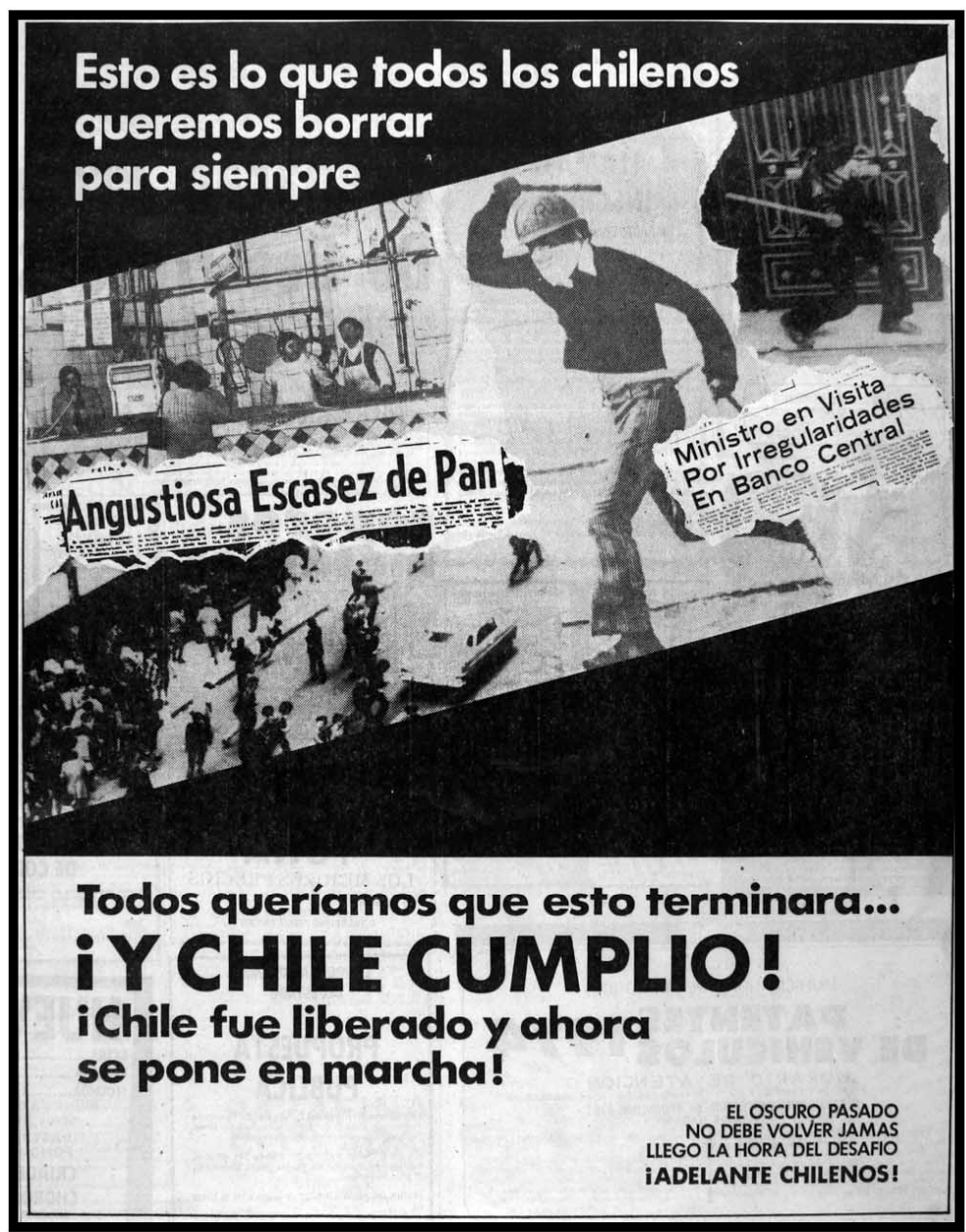

Lámina 12

Y Chile Cumplió, 8 de marzo de 1974; Santiago.(El Mercurio) Biblioteca Nacional de Chile. 

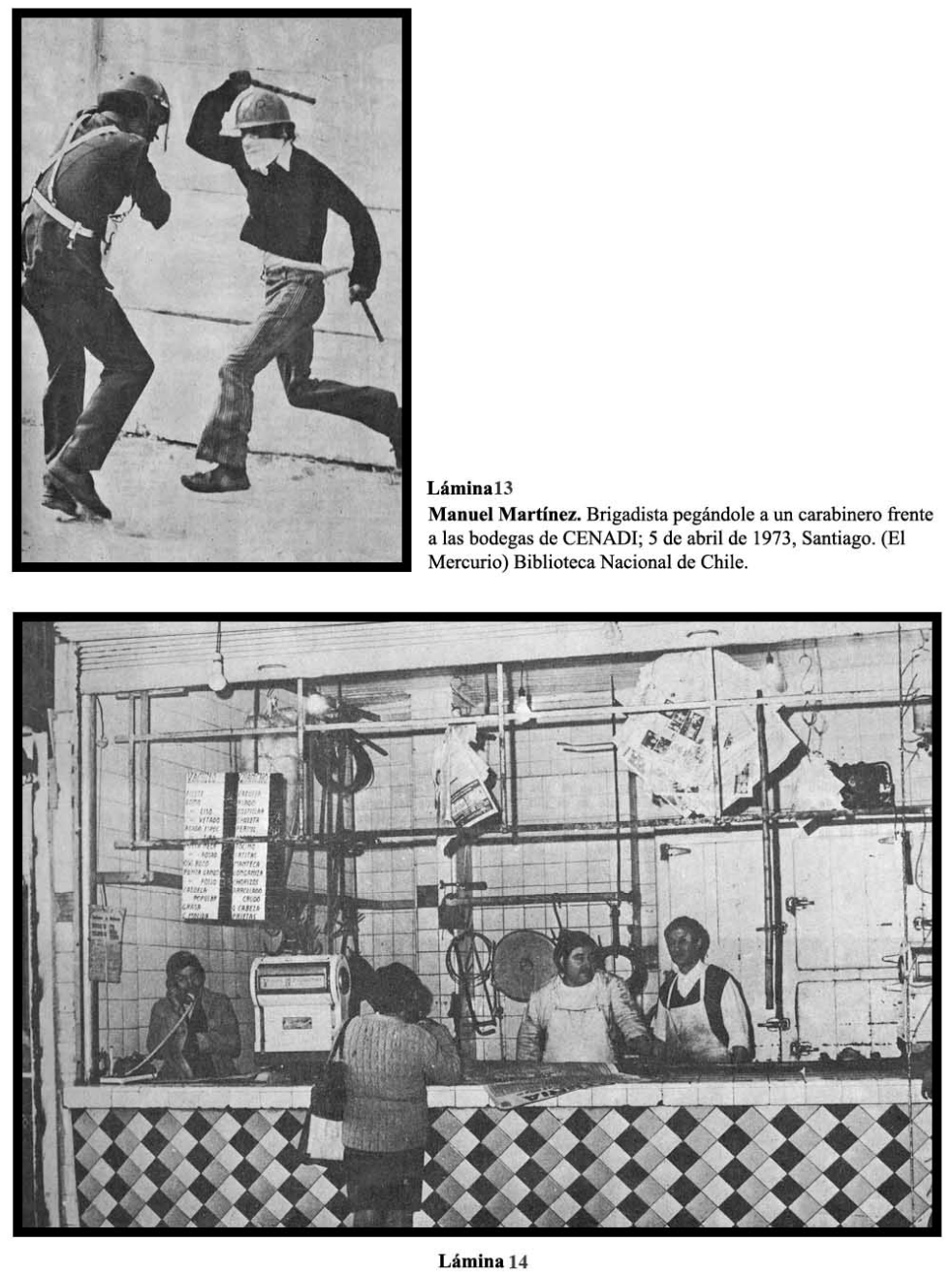

El comercio vació.(ASIMPRES) Biblioteca Nacional de Chile.

Sin duda, la Junta Militar manejó y utilizó las instituciones sociales y políticas, y particularmente, las instituciones relacionadas con los medios de comunicación, que participan en la estructuración de un nuevo universo simbólico por medio de las palabras y las imágenes fotográficas. Vemos, entonces, que cada imagen analizada es producto de una representación totalizante de la sociedad con un orden determinado, según el cual 
cada elemento y cada sujeto tiene su lugar, su identidad y su razón de ser en la nueva estructura política y social que la Junta Militar le dio al país.

Es por ello que estimamos que la publicación de la obra fotográfica Chile: ayer y hoy obra sin año de publicación- se haya realizado durante los años 1975 y 1976; años de mayor adhesión, cohesión y aprobación del gobierno militar. Chile: ayer y hoy representa un pasado que se quiere dejar en el olvido y un presente que arrasa, extirpa y anula el pasado histórico de un país. La obra está conformada por un grupo de aproximadamente noventa imágenes fotográficas cuyo relato nos revela el primer "rostro" de la dictadura (Ver lámina № 15).

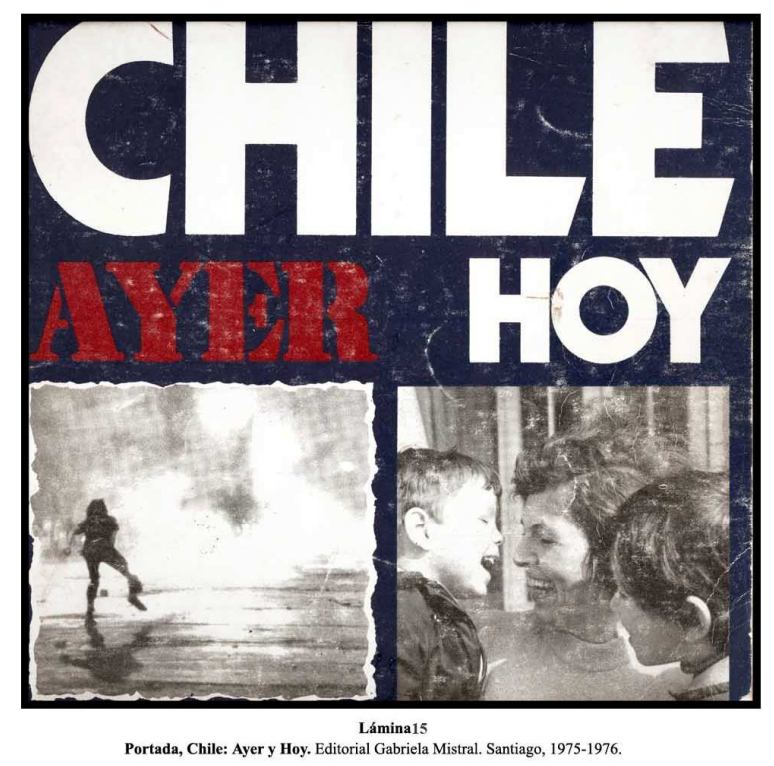

La obra publicada por la editorial Gabriela Mistral, no señala fecha de publicación, ni los fotógrafos, ni sus editores, como si fuese gestada por un acto mágico, o por generación espontánea. ¿Quién construye ese rostro y quién le da forma? La Junta, pues la editorial Gabriela Mistral nace junto con la dictadura. Es uno más de los tantos brazos que utilizó el sistema. ¿Pero cómo nace la editorial? Con posterioridad al golpe de Estado, la editorial nacional Quimantú fue tomada y allanada por las fuerzas militares. Una vez reestructurada la empresa, adoptó el nombre de Editorial Nacional Gabriela Mistral, reduciendo los 
tirajes y heredando los formatos de Quimantú con sus títulos en Univers condensada y Stencil?.

La portada de esta obra nos presenta dos fotografías, una al lado de la otra. En la fotografía del lado izquierdo sus orillas han sido rasgadas, las fotografías del lado derecho del encuadre son pulcras y bien cuidadas. La imagen de la izquierda es borrosa, pareciera que fuese una calle; una persona se ve parada en ella, su rostro es irreconocible a nuestra mirada. Su figura negra está en una posición extraña, como si hubiese tirado algo. Por otro lado, la fotografía de la derecha muestra el rostro de una mujer y dos niños riendo. Cada una lleva un título sobre ellas.

Las letras de la fotografía izquierda son grandes y rojas, y aluden a una tipografía stencil, pues si enfocamos la mirada, el diseño entrecortado con pequeñas interrupciones nos hace creer que es así. ¿̇Por qué utilizaron este tipo de tipografía?, ¿por qué son distintas al resto de las tipografías de la misma tapa de la obra?, zqué nos quieren decir con esto? Si nos fijamos en las murallas de las calles, en los postes de luz o en los paraderos de la movilización colectiva, podemos encontrar dibujos o letras tipo stencil, como también en los sacos de harina, en las cajas de armamento militar o en alguna película de acción. No está demás señalar que el esténcil o estarcido ha estado relacionado a la propaganda política. En 1933 David Alfaro Sequeiros escribía sobre el esténcil como una herramienta estética política, de fácil uso, y que por sus características prácticas reduce el tiempo de riesgo ante el acoso policial. ¿Qué connota esta letra?, ¿tendrá alguna relación con su imagen?

Nuestra mirada sigue recorriendo la portada. La ruta que siguen nuestros ojos al efectuar el registro es compleja, ya que confluyen dos elementos que es necesario dilucidar. Por un lado, la imagen en sí tiene una estructura dada según la forma en que es utilizado su lenguaje, y del otro lado, están nuestras propias intenciones al observar la imagen. El significado de la imagen como lo revela el registro es, entonces, la síntesis de dos intensiones: la manifiesta en la imagen misma y la manifiesta en el observador. Por lo tanto, las imágenes no son conjuntos de símbolos denotativos como los números, sino conjuntos de símbolos connotativos: las imágenes son susceptibles de interpretación.

Teniendo en cuenta lo anterior, la portada de Chile: ayer y Hoy muestra un Estado de sitio permanente, reproduciendo la lógica de seguridad nacional. En su dicotomía, su

\footnotetext{
${ }^{9}$ A fines de 1973 la editorial Quimantú es expropiada por el gobierno militar convirtiéndose en la Editorial Nacional Gabriela Mistral a la cabeza del General Diego Barros Ortiz como máximo directivo y como presidente de un consejo conformado por algunos intelectuales del régimen como Enrique Campos Menéndez y Fernando Campos Harriet. Posteriormente, en 1976, se venden sus maquinarias y aparejos a Juan Fernández Montalvo, propietario de la imprenta y litografía Fernández. Adquiriéndolos en sociedad con Rodolfo Letelier y Guillermo Tolosa.
} 
juego de oposiciones marca un antes y un después. La letra stencil roja nos habla del partido comunista, del gobierno de la unidad popular. Letra roja como la bandera de la Unión Soviética, letras militantes en el sentido más profundo de la palabra. Al unirla con el encabezado "Chile, ayer" todo cobra sentido.

La fotografía de la derecha y su texto en letra univers envuelve otro contenido. Ideológicamente este tipo de tipografía revindica las formas de escritura del pasado, pues se revaloró el paloseco. Sus formas no se basan en el antiguo carácter lineal por poseer trazos ostentosos de un tipo de letra que pretende rebelarse contra todo lo anterior, sino más bien pretende relacionarse mentalmente desde esa perspectiva, entre el contraste romano y el paloseco, es decir, haciendo directa alusión a la cultura antigua occidental (Futiger, 2002). Cultura que el gobierno militar quiere destacar.

En la imagen correspondiente al Chile de hoy, connotativamente la mujer aparece como un elemento muy relevante, pues el discurso dictatorial apelaba a las mujeres, como en los afiches que se reproducían en El Mercurio (Ver lámina No 16). Para la dictadura, la mujer juega un rol fundamental como ente aglutinante de la familia y de los valores que se deben inculcar. ¡Este es el Chile de hoy, de la Junta Militar! Tomemos en cuenta que en el momento más álgido de caos durante el gobierno de la Unidad Popular, fue un grupo de mujeres de la burguesía quienes salieron a las calles con cacerolas y sartenes protestando contra el gobierno y exigiendo el pronunciamiento del Ejército para que se pusiera fin a la situación que se vivía en aquel entonces. Para la dictadura: "las madres chilenas han advertido que donde ayer había corrupción hoy existe dignidad, y donde reinaba la angustia de la desesperanza hoy se vive un dolor compensado por signos de fecundidad" (A seis meses de la liberación nacional, 1974, p. 44).

Avanzando en el análisis nos encontramos con dos páginas que llaman la atención: una contraportada negra donde aparece una fotografía de Allende con un rifle en la mano, seguida de una página en blanco con la imagen de un amanecer (Ver lámina № 17-18). Tomando el pensamiento de Barthes, si la imagen no fuera muda, nos hablaría de quién realizó este relato, quién fue su diseñador y cuál es la fecha de su publicación. Sin embargo, lo es. Ella permanece muda ante los ojos del espectador esperando ser traducida y explicada en tres idiomas: español, inglés y francés. El Chile: Ayer y hoy se plantea como un embajador políglota que explica de manera fehaciente la realidad chilena, con la intensión de que el país y su realidad se muestren al mundo.

En el caso de que estas imágenes fuesen realmente el rostro de Chile -si ellas nos indicaran un "eso ha sido" constatando un acontecimiento objetivamente-, se interpondrían entre el hombre y el mundo. Ellas pretenden ser mapas del mundo, pero verdaderamente se convierten en pantallas. Tomando las palabras de Vilem Flusser: "En vez de presentar el mundo al hombre, lo re-presentan; se colocan en lugar del mundo a tal 
grado que el hombre vive en función de las imágenes que él mismo ha producido" (Flusser, 1990, p. 12).

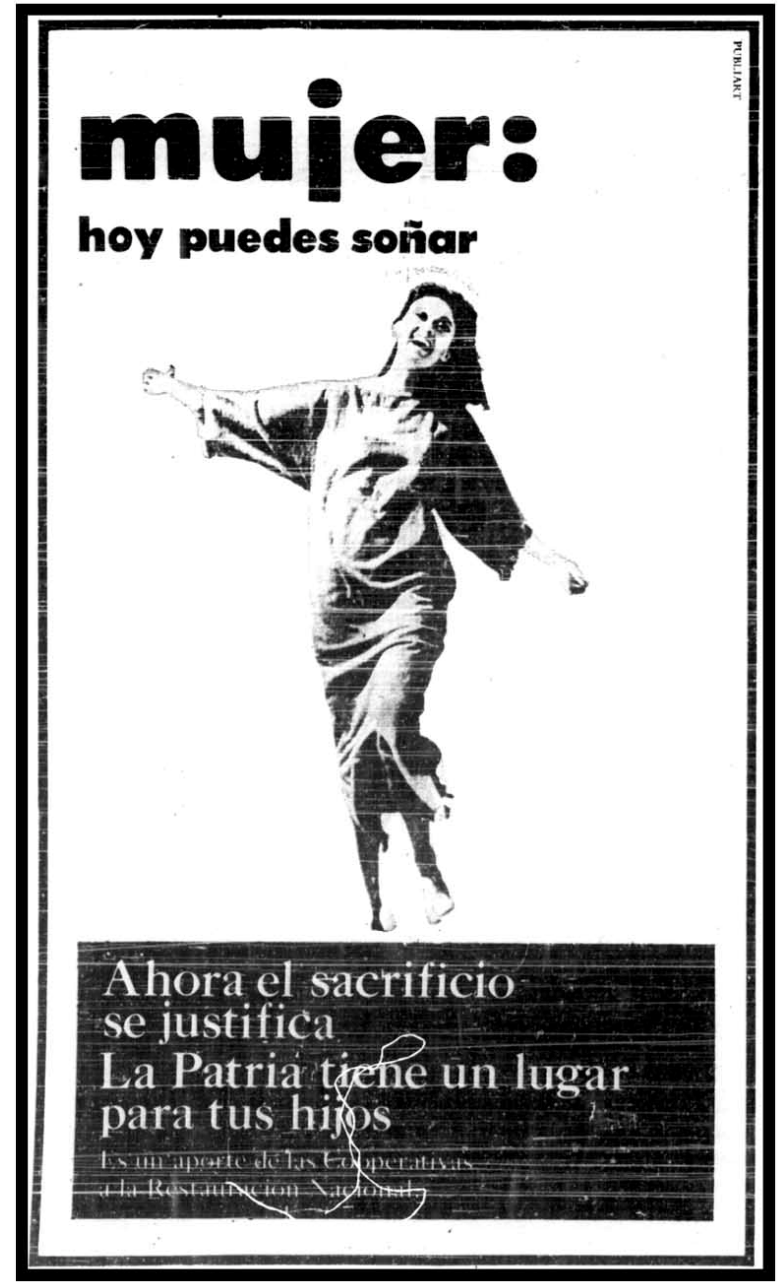

Lámina16

Mujer hoy puedes soñar. (El Mercurio). 


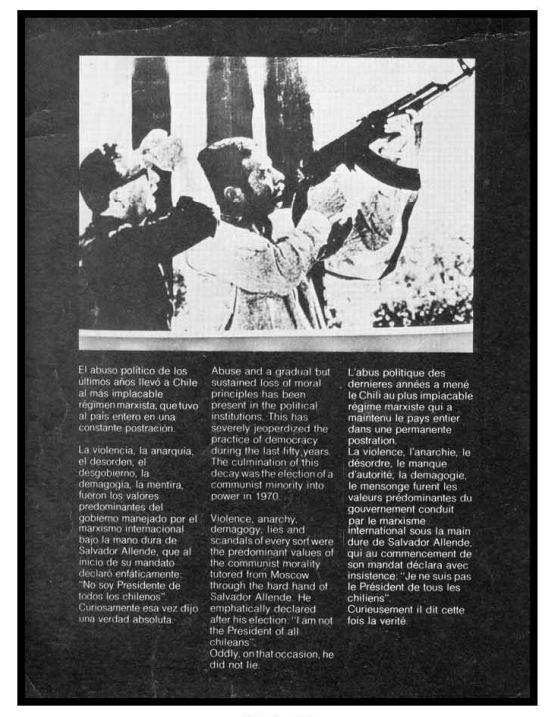

Lámina17
Chile: Ayer y Hoy. Editorial Gabriela Mistral. Santiago, 1975-1976.

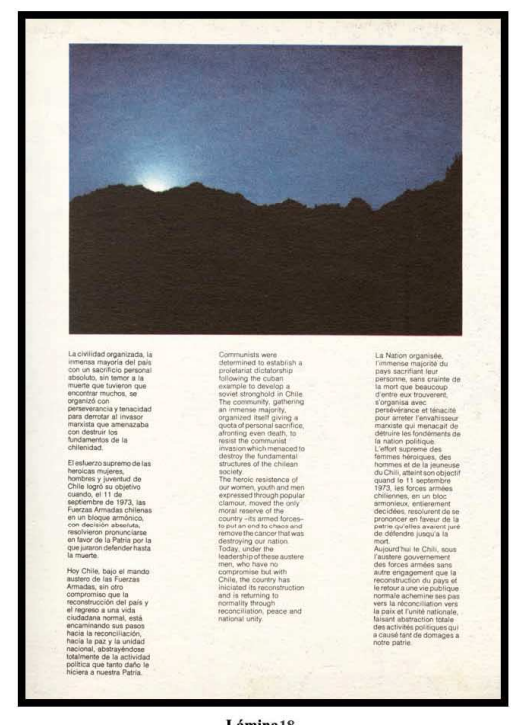

Chile: Ayer y Hoy. Editorial Gabriela Mistral. Santiago, 1975-1976.

Continuando con el estudio de la obra, las fotografías parecieran ser todas iguales, ya que en la mediada que avanza el relato estas no nos sorprenden. Si hojeamos el Chile: Ayer $y$ hoy, quedamos con la sensación de haber visto esas imágenes en algún otro lugar $\mathrm{y}$, justamente, parte de su atractivo radica en ello (Lámina No 19-20). Esto se debe a que la gran mayoría fueron sacadas como fotografías periodísticas sin una finalidad estilística o sello propio, pues su importancia estaba en el referente y no en la fotografía en sí misma. Las fotografías se nos hacen redundantes. Esa es la intensión de esta obra, ser repetitiva en las ideas que pretende inculcar tanto en sus lectores nacionales como internacionales, puesto que su narración reitera los valores que se intentaban concientizar, impregnándolos en el imaginario social.

Tomando las palabras de Barthes, las fotografías son interesantes por su studium "ya sea porque las recibo como testimonios políticos, ya sea porque las saboreo como cuadros históricos buenos (Barthes, 1992, p. 64). En consecuencia, la importancia de Chile: Ayer y hoy radica en que es un fiel testimonio de una retórica; la obra revela un lenguaje que existió alguna vez, en otro tiempo. La fotografía actúa como un texto fotográfico, "como cualquier otro, es un lugar de una compleja 'intertextualidad', de una serie superpuesta de textos previos 'dados por hechos' en una coyuntura cultural e histórica concreta" (Batchen, 2004, p. 17), generado por superposiciones de consignas: patria=bandera; 
caos/orden; desabastecimiento/abundancia, etc. (Ver lámina o 16-17). Como vemos, este tipo de composición crea un sentido de temporalidad específico, el pasado reciente se interpreta como un tiempo oscuro que se debe borrar por la llegada de la luz salvífica de la Junta Militar.

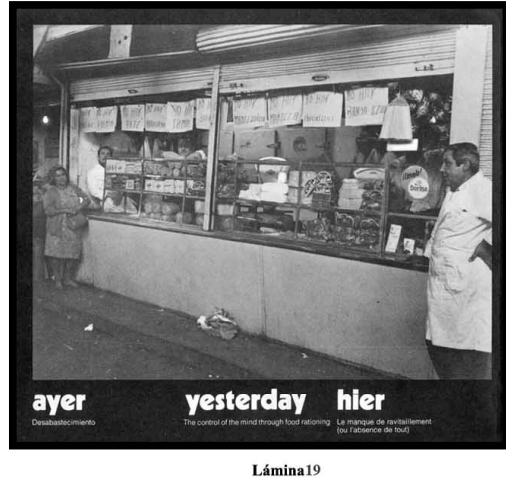

Ayer. Desabastecimiento. Chile: Ayer y Hoy. Editorial Gabriela Mistral. San-
tiago, $1975-1976$.

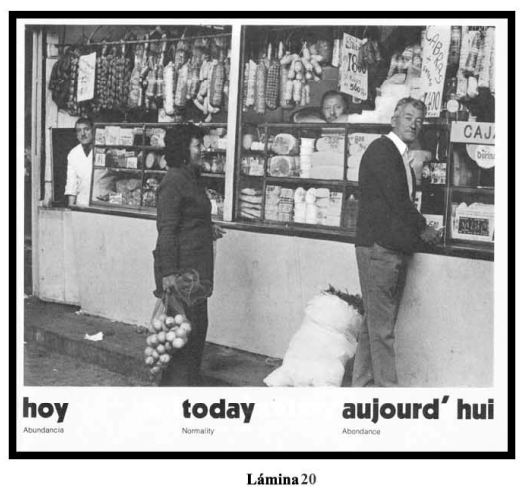

Hoy. Abundancia. Chile: Ayer y Hoy. Editorial Gabriela Mistral. San-
tiago, 1975-1976.

Por otro lado, en esta obra, texto e imagen conforman el relato. "El pie de foto precisa de manera explícita el sentido de una imagen, pero así como no hay pensamiento sin palabras, de la misma manera no hay percepción visual sin recurrir a una articulación común a la del lenguaje" (Bauret, 1999, p. 38). Las fotografías van ligadas a un lenguaje especial, si unimos los pies de foto, se reproduce la dicotomía antes mencionada. Es por ello que se hace coherente la imagen y pie de página con el tipo de contenido que se pretendía vincular.

Pero, además, si unimos las páginas con fondo negro del ayer, a las fotografías con fondo blanco del hoy, en su conjunto forman un sub-relato de los principios y valores que asumía la Junta como gesta heroica refundadora del Estado nacional (Ver lámina № 1819). Por otro lado, si miramos la concatenación o secuencia bajo las ideas barthesianas podemos apreciar que el significando de connotación es ideológico (Barthes, 1986), ya que si observamos la sintaxis de la obra fotográfica esta se basa en un juego de dicotomías 
entre una fotografía y otra; repitiéndose una y otra vez, cuando avanzamos en su lectura. Este juego se refuerza con las palabras Ayer versus Hoy, es decir, antes del golpe de Estado y después de éste.

Con todo, la obra Chile: Ayer y hoy revela en sus imágenes las políticas comunicaciones en dictadura, donde la fotografía tuvo un papel preponderante. Al igual que el Estado, la obra fotográfica no es neutra. Las representaciones que nos muestran y relatan no se enmarcan dentro de una creación espontánea, sino que responden a códigos preestablecidos por el régimen imperante, de ahí que el poder que ejercen no nazca enteramente de ellas, sino de la conjunción de distintos elementos.

A raíz de esto, como medio testimonial, las imágenes fotográficas son escenificadas e investidas de realidad, haciendo referencia al carácter de objetividad que tradicionalmente se le ha dado a la imagen fotográfica como un elemento que es capaz de capturar la espontaneidad de un momento en particular, interrumpiendo y mostrando la vida cotidiana según la visión de mundo que el gobierno quiere representar.

En suma, las políticas comunicacionales, como lo hemos visto, apuntaban a fortalecer una idea-imagen acorde con los principios legitimadores y restauradores fundados por la Junta Militar. Según Bronislaw Baczko:

Todo poder busca monopolizar ciertos emblemas y controlar, cuando no dirigir, la costumbre de otros. De este modo, el ejercicio del poder, especialmente del poder político, pasa por el imaginario colectivo. Ejercer un poder simbólico no significa agregar lo ilusorio a un poderío 'real', sino multiplicar y reforzar una dominación efectiva por la apropiación de símbolos, por la conjugación de las relaciones de sentido y de poderío (Baczko, p16).

A nuestra manera de ver, las imágenes fotográficas, como objeto cultural, develan aquel discurso legitimador y hegemónico que la dictadura quería plasmar. Por medio de ellas se ofrecía una nueva identidad de Chile, un nuevo rostro para la sociedad, pues la fotográfica podía entregar y designar una imagen acorde con el discurso dictatorial. Ya que gracias a su lenguaje simbólico nos permite conocer el mundo de otra manera, "nos alejamos de la materialidad del mundo, para acercarnos a él de manera simbólica" (Concha, 2001, p. 270).

\section{Referencias}

A seis meses de la liberación nacional. Mensaje al país del presidente de la junta de gobierno, General Don Augusto Pinochet Ugarte, pronunciado el día 11 de Marzo 1974, al cumplirse seis meses de gobierno. (1974). Chile: Editorial Gabriela Mistral. 
Baczko, B. (1999). Los Imaginarios Sociales. Memorias y esperanzas colectivas. Argentina: Ediciones Nueva Visión.

Bando No 5 de la Junta de Gobierno de Chile. (1973, 11 de septiembre).

Bauret, G. (1999). De la Fotografía. Argentina: Editorial La Marca.

Barthes, R. (1986). Lo obvio y lo obtuso: imágenes, gestos y voces. Barcelona: Editorial Paidós.

----- (1992). La Cámara Lucida. Barcelona: Editorial Paídos.

Batchen, G. (2004). Arder en deseos. La concepción de la fotografía. Barcelona: Editorial Gustavo Gili.

Burgin, V. (2004). Ensayos. Barcelona: Editorial Gustavo Gili.

Campaña de Penetración Psicológica Masiva. (Octubre de 1973 a marzo de 1974). Dirección de Relaciones Humanas. Secretaria General de Gobierno. Obtenido 30 de agosto de 2004 en http://www.lanacion.cl/p4_lanacion/documentos/archivos_miedo/secreto2/2sicologica.h tml.

Cavallo, A. (1997). La historia oculta del régimen militar. Chile: Editorial Grijalbo.

Cleary, P. (1988). Como nació la pintura mural política en Chile. Revista Araucaria. No42, pp.193195.

Concha, J.P. (2001). Imagen Fotográfica y lenguaje. Revista Aisthesis. No 34. Chile: Pontificia Universidad Católica de Chile.

------- (2004). Más allá del referente, fotografía. Del Index a la palabra. Chile: Pontificia Universidad Católica de Chile.

Chile. Ayer y hoy (1974-1976). Chile: Editorial Nacional Gabriela Mistral.

Decreto de ley $N^{\circ} 1$ de 11 de septiembre de 1973. Acta de Constitución de la Junta de Gobierno (1973, 18 de septiembre).Chile: Diario Oficial.

Del Valle Gastaminza, F. (2005). La fotografía como objeto desde la perspectiva del análisis documental. En Aguayo, F. y Roca, L. Imágenes e investigación social. Mexico: Instituto de Investigaciones Dr. José María Luís Mora.

Dos ensayos sobre Seguridad Nacional. (1976). Chile: Arzobispado de Santiago, Vicaria de la Solidaridad.

El Mercurio. (1974). Breve historia de la Unidad Popular. Chile: Editorial Lord Cochrane.

Filippi, E y Millas, H. (1973). Anatomía de un Fracaso. La experiencia socialista chilena .Chile: Editorial Zig-Zag.

Flusser, V. (1990). Hacia una filosofía de la fotografía.Mexico: Editorial Trillas.

Futiger, A. (2002). En torno a la tipografía. Barcelona: Editorial Gustavo Gili.

León, C. (1983). El muralismo chileno. Comunicacion y artes populares. Revista Araucaria No24, pp.109-117.

Líneas de acción de la Junta de Gobierno de Chile. (11 de Marzo de 1974). Santiago: Editorial Nacional Gabriela Mistral.

Preparación Psicológica de la población para contrarrestar la acción marxista (19 de noviembre de 1973). Chile: Asesoría Civil. Depto. Relaciones Humanas y Conducta social. Secretaria General de Gobierno. Obtenido en agosto 2004 en 
http://www.lanacion.cl/p4_lanacion/documentos/archivos_miedo/secreto/1sicologica.ht $\mathrm{ml}$.

Poole, D. (2000). Visión, raza y modernidad. Una economía visual del mundo andino de imágenes. Perú: Editorial Sur- Casa de estudios del Socialismo.

Sobre la necesidad de realizar una campaña Psicológica-masiva tendiente a destruir al marxismo como ideología (7 de julio de 1974). Chile: Dirección de Relaciones Humanas. Secretaria General de Gobierno. Obtenido en agosto 2004 en

http://www.lanacion.cl/p4_lanacion/documentos/archivos_miedo/secreto3/3sicologica.h tml.

Secretaria General de Gobierno. (1973). Libro Blanco. Del cambio de gobierno en Chile. Chile: Editorial Lord Cochrane.

Sunkel, G. (1983). La producción de información de la Prensa diaria bajo el régimen autoritario. Notas exploratorias. Chile: CENECA.

Tagg, J. (1999). El peso de la representación. Ensayos sobre fotografías e historias. Barcelona: Editorial Gustavo Gili.

Tres años de destrucción (1973). Chile: ASIMPRES.

Vergara, A. (2003). El Reportaje a Chile. En: Rolle, C. 1973, La vida cotidiana de un año crucial. Chile: Editorial Planeta. 